\title{
Procuratores: On the Limits of Caring for Another
}

\section{Citation}

Hamilton, J. T. 2015. "Procuratores: On the Limits of Caring for Another." Telos 2015 (170)

(March 1): 7-22. doi:10.3817/0315170007.

\section{Published Version}

10.3817/0315170007

\section{Permanent link}

http://nrs.harvard.edu/urn-3:HUL.InstRepos:23953009

\section{Terms of Use}

This article was downloaded from Harvard University's DASH repository, and is made available under the terms and conditions applicable to Open Access Policy Articles, as set forth at http:// nrs.harvard.edu/urn-3:HUL.InstRepos:dash.current.terms-of-use\#OAP

\section{Share Your Story}

The Harvard community has made this article openly available.

Please share how this access benefits you. Submit a story.

Accessibility 
John T. HAMILTON

\section{PROCURATORES \\ ON THE LIMITS OF CARING FOR ANOTHER}

In considering the Latin provenance of the terms, both security (securitas) and at least one specific form of representation (procuratio) explicitly hinge on some idea of care or concern (cura): securitas spells the removal (se-) of care; while procuratio designates how an agent takes care of some task for (pro) another. Yet, far from unequivocal, the word cura operates along two divergent semantic trajectories. On the one hand, cura may denote the assiduous concern that one devotes to a person or object, or, in fact, even the object of concern, like the beloved addressed in Roman elegy or the poem itself. On the other hand, cura names an anxious concern or emotional trouble; in a sense that relates to the former, cura may be directly tied to the fear that the object of concern is somehow under threat. ${ }^{1}$ The ambivalence that haunts most of our modern security projects could be reduced to a simple double bind: In removing concern, securitas promises to produce a state that is carefree, while also introducing the risk of rendering someone careless. $^{2}$ As Roman Epicureans and Stoics underscore, a person is literally secured, when he or she is liberated from worry or care. All the same, proceeding without care potentially hazards correlative problems of complacency, apathy, or negligence. This result is particularly relevant when some instituted power claims to care or worry in that person's stead. The question, then, is whether political or legal representation (procuratio) harbors similar perils, for the transference of care that is discernible in security projects also obtains in the representative functions of the procurator-the officer who takes on a specific concern for another. If security betokens a political condition that imposes greater control over a population under the auspices of freeing the people from fear, and if this usage of power can all too readily backfire in 
abuse, then political or legal representation may reveal a similar logic: the intervention that proposes to take care of someone else's affairs may possibly go wrong in any number of ways. In focusing on the figure of the procurator, the analyses that follow trace out some of the forms and ideological presuppositions that interrogate the limits of representative caretaking, first with an example from Franz Kafka's Metamorphosis and then with two relevant examples from Latin poetry, from Ovid and Martial.

Both security and political representation are generally understood as constitutive of modern liberalism, especially when this term is defined as a doctrine that aims "to secure the political conditions that are necessary for the exercise of personal freedom."3 Although the texts discussed here clearly precede the particular liberalist policies that came to the fore in the Cold War and its aftermath, a consideration of the historical usage of key terms should shed some important light on the dilemmas that invariably emerge in balancing the demands between individual freedom, political representation, and the security state. At issue is the central concept of cura-a concept fraught with the kind of ambivalence that all too readily opens the door to possible abuse. In removing care by assuming all care, the security apparatus may not only promote a certain carelessness among the citizenry, it may also do so with the assurance that it holds its constituency as the chief concern. Insofar as liberalism strives first and foremost to secure personal freedom by means of political representation, it implies the presence of a systemic threat that invariably renders freedom impossible. As we shall see, the figure of the procurator, although grounded in republican institutions, retains the horrors of absolutism that these very institutions sought to dispel.

One morning, after Gregor Samsa awoke to find himself transformed into a monstrous vermin, moving with great difficulty and unable to get ready for work, he received an embarrassing visit from one of his company's chief administrators: "the Prokurist himself." ${ }^{4}$ As this early scene in Kafka's Metamorphosis relates, the fact that an employee missed his morning train is clearly an urgent concern for the corporation, which consequently sends this high-ranking official to investigate the 
matter; and it is no surprise that the man's arrival greatly disturbs an already disturbing scene. Like Georg Bendemann of Kafka's The Judgment (Das Urteil), Gregor feels and is in fact condemned, not to "death by drowning" but rather to immediate and deep suspicion. By missing a single day of work, Gregor is already singled out. The narrator reflects on this exceptional status: "Why was Gregor the only one condemned [verurteilt] to work for a firm where one immediately fell under highest suspicion at the slightest shortcoming?" (100/94) Notions of judgment of course play a central role in Kafka's imagination; and here, in The Metamorphosis, it is noteworthy that the personal vehicle of condemnation is a Prokurist, whose functions include both representation and execution, both speaking for the company and carrying out its policies. In accordance with Austrian business practice, the Prokurist is the agent who has been delegated "full power of attorney" (Prokura), the pleinpouvoir or Vollmacht, to inspect the case on the firm's behalf. He is therefore not merely a messenger, nor is he simply a Stellvertreter ("representative"), but rather a Bevollmächtigter, an authorized commissary who conducts himself with all the assurance expected of someone who has the full weight of the corporation behind him. On this basis, the Prokurist demands the greatest respect: precisely the kind of respect that Josef $\mathrm{K}$. in The Trial fails to get from the magistrate, who mistakes him for a common "housepainter" rather than "first Prokurist of a large bank." ${ }^{5}$ As Gregor must know, a visit from "the Prokurist himself" is a serious matter, insofar as this agent has the authority to adjudge the situation and take action. Gregor is condemned because, when this man speaks, it is the company itself that speaks. Endowed with the company's Vollmacht or warrant, the Prokurist essentially turns the employee's private living quarters into an extension of the office. Although Gregor has missed the train, he nonetheless finds himself in the workplace, struggling to excuse his behavior before his superior. The Prokurist bears the power to transform Gregor's home into a branch of the company. With Kafka, one metamorphosis deserves another.

The representative and executive capacities of the modern Prokurist reach back to a long tradition in Roman law and culture, namely to the figure of the procurator. As the term suggests, the procurator is someone who personally 
assumes a "concern" or "care" (cura) "for" (pro) another. In the definition provided by the late imperial jurist Ulpian, preserved in the Digest, "the procurator is one who administers another's business on a mandate from his lord" - Procurator est qui aliena negotia mandatu domini administrat. ${ }^{6}$ Thus, the procurator is charged with the "superintendence" or "management" (procuratio) of certain affairs, adopting someone else's matters (aliena negotia) as his own and acting appropriately. Although procuratio covers a broad semantic range, denoting a general "caring for," it is important to stress that in the restricted case of the authorized procurator, the prefix pro- qualifies a concern that has been taken up in the name of and in place of a higher authority (mandatu domini).

The institution of engaging someone to handle the affairs of one who is absent had been well established in the early Republic. Initially, out of consideration for the elderly or the sick, it became advisable to relax the old principle that a litigant must appear in person to defend his rights before the court. Then, as the Republic continued to expand its geographical reach and ambitions, it was quite common for a Roman lord to designate one of his sons or slaves to take care of local business while he was away on other enterprises or on the service of the State. ${ }^{7}$ Over time, in order to legitimize the procurator's actions, this role was granted to a freedman, who was attached to the property as a capable and efficient manager. Accordingly, Cicero frequently employs the figure of procurator to describe the ideal orator-statesman as someone possessing solid theoretical knowledge and practical skills. For example, in De Oratore, Cicero makes reference to his teacher, the renowned orator and consul, Lucius Licinius Crassus, as one occupied with the "management of the entire world [orbis terrae procuratione] and the government of a vast empire [summi imperi gubernatione]." 8 The orator-statesman is like a procurator, insofar as he knows how to take effective care of the Republic. ${ }^{9}$

By the beginning of the Principate, the title of procurator does in fact expand to include not only financial officers, who collected revenues on behalf of the emperor, but also so-called "praesidial procurators," who were generally selected from the equestrian class - military officers, but also former tribunes and centurions, who were thus granted governorship of remote provincial areas. ${ }^{10}$ 
Under Claudius, the procurator provinciae exercised significant judicial and military authority, and was therefore frequently construed as a praefectus. In this way, the procurator became a key figure of civil service, "taking care" of a host of issues, performing a procuratio for the people but also for the authorities. The core concept of deputization would persist well after the dissolution of the Roman Empire, continuing to specify the nature of the procurator's mandate throughout the Middle Ages and into modern European culture. It is on the basis of deputized action that modern procedures of political and legal representation gradually developed. As with Ulpian, the representative assumes the cares of his or her constituency, ideally working by the people's mandate.

That the caretaker of the people in fact serves the state tends to shift the meaning of this procuratio away from the sense of the German Fürsorge ("welfare, administered aid"), despite the close morphemic correspondence. The difference rests on the implied object of the prepositional force of the prefix. Whereas the für in Fürsorge governs the recipient of concern, the pro- in the procurator's procuratio is more often associated with the source of concern. ${ }^{11}$ The Fürsorger cares for someone who will enjoy a benefit, while the procurator takes care of something for an authority that has granted him the power to do so. Although not rigorously maintained, a distinction could be made between Fürsorge and Prokura as reflecting the difference between caring for someone and taking care of something for someone, respectively. As we have seen, Kafka's Prokurist arrives not to offer assistance to Gregor but rather to condemn him in the name of the firm.

In Kafka's text, the specific structure of the Prokurist's mission as procurator - taking care of something for someone - proves to have many ramifications for understanding the idea of representation tout court. When the distinguished bureaucrat speaks at Gregor's closed door, he stands on full authority, including the now enfeebled authority of the parents: "I am speaking here in the name of your parents and your boss [im Namen Ihrer Eltern und Ihres Chefs], and ask you quite seriously for an immediate and clear explanation" (103/97). The formula, to speak in the name of someone else, operates here on at least two levels. On the one hand, it derives from the language of the oath. According to Émile Benveniste, invoking the 
name of the other contributes nothing to the semantics of what is said, but rather simply guarantees the efficacy of the statement. ${ }^{12}$ The speaker summons an authority to serve as witness to the validity and trustworthiness of what is pronounced. The oath thus depends on an act of faith, namely that the speaker truly represents what he claims to represent, that he is not, in the language of jurisprudence, a falsus procurator. Sealed by a fiduciary bond, the agent promises to serve as an ideal representative, like the high-minded protagonist in Goethe's "Prokurator" from the Unterhaltungen deutscher Ausgewanderten, who is characterized as inspiring "the power of virtue."13 On the other hand - and this aspect is brilliantly brought out by Kafka, who has the Prokurist invoke both the name of Gregor's boss and the name of his parents - the invocation forcefully places the speaker in the authorities' stead. The fearful man, who has intruded on the Samsas' domestic space, speaks in the name of the father and the mother, despite the fact that they are present in the room. In speaking for the parents, and ostensibly for the firm as well, the Prokurist relegates all other authority to silence and absence.

This silence and absence should not detract from the "alien" nature of the procurator's business. On the contrary, the notion of aliena negotia is worth underscoring. The Prokurist in his bodily presence addresses a problem that does not, strictly speaking, originate from his own subjective position. He operates instead as though it were an issue of his own personal interest. Again, the Prokurist represents the firm, which through him acts by proxy - an English variant spelling of the archaic term procuracy. His legitimacy is based on the transferability of rights. Yet the agency of this proxy figure remains complicated: the Prokurist's concern is and is not his own; or rather, it is his concern by virtue of not being solely his concern. A minimal gap or difference, discernible in every case of representation, qualifies the agent's mandate; it is what allows us to distinguish the representative from whom or what he represents. Cicero provides a definition of the procurator that perfectly recognizes the dissimilarity that regulates every similarity:

Procurator dicitur omnium rerum eius qui in Italia non sit absitue rei publicae causa quasi quidam paene dominus, hoc esti alieni iuris vicarius. ${ }^{14}$ 
The procurator of all matters is said to be the agent of someone who is not in Italy, of someone absent on business of the republic, as if he (the procurator) were almost a certain sort of master, that is, a deputy possessing the rights of another.

"As if he were almost a certain sort of master" (quasi quidam paene dominus), the agent is characterized by a system of representation that closely connects the emissary to the authoritative body by keeping them separate. To be sure, this slight écart is the precondition that enables us to recognize the procurator's words as a speaking-for, which must not be confused with the originating speech.

All the same, as the scene in the Samsas' apartment unfolds, we realize that the agent's power is efficacious only when this distinction is overlooked, when the one who is "almost a certain sort of master" essentially becomes the master. The implication of Vollmacht is that the representative is to be regarded as the incarnate presence of the absent authority. The discourse of power, channeled by proxy, is based on an idea or ideology of identity, which overrides the dissimilar similarity that would otherwise mark a representative as a representative. As Gregor grows more and more nervous in the confines of his small room, his father and mother, who already regard their son as a worrisome "concern" ("Sorge"), readily subordinate themselves to the Prokurist, as though (quasi) they were face to face with the company itself. Ulpian concurs: Quae acta gestaque sunt a procuratore Caesaris, sic ab eo comprobantur, atque si a Caesare gesta sunt (Dig. 1.19.1) - "Those things which are acted and done by Caesar's procurator, are so approved by him, as if they have been done by Caesar himself."

This gesture of legal fiction, which aims to eradicate the distinction between the representative and the represented party, is further discernible in Ulpian's juridical elaboration of the procurator's role. Upon specifying procuratio as the administration of another's business, Ulpian is quick to restrict the agent's mandate, while adding a crucial exception: Alteri stipulari nemo potest, praeterquam si servus domino, filius patri stipuletur (Dig. 45.1.38.17) - "No one can make a stipulation on behalf of another, except if a slave makes a stipulation for his master or a son for his 
father." Stipulations - verbal agreements or contracts - therefore are not binding: a third party may handle business affairs, but promises made in the course of these proceedings bear no legal obligation; except, however, in the case of a slave or a sonin-power, where such promises are indeed binding. This exception makes sense only when the slave and the son are not considered legal subjects in their own right. ${ }^{15}$ The agent in these exceptional cases is understood simply as an extension or organ of the empowering authority. That said, the identification of two distinct persons, which renders the speaking-for efficacious, can work in two ways: either the procurator effaces his principal or he is absorbed into the corpus of the authorizing corporation. The ideology of identification, which is now taken as the effacement of one of the parties, is precisely what has always distinguished the procurator from a mere "messenger" (nuntius), where no such effacement takes place. With the messenger, the representation, its source and its vehicle all remain or should remain rigorously distinct; with the procurator, all are conflated.

Nonetheless, in Kafka's Metamorphosis, the spell of identification is finally broken, when the Prokurist catches cite of the gigantic, hideous insect. Gregor emerges from his room to explain his behavior to the company's manager. Up to this point, Gregor has been depicted solely as a son and as a servant of the firm, as a filius and a servus - designations underscored by the Prokurist's initial invocation, speaking in the name of his "parents" and his "boss." Yet, when Gregor appears in the living room, he speaks only for himself. The performance crucially modifies the Prokurist's behavior:

Aber der Prokurist hatte sich schon bei den ersten Worten Gregors abgewendet, und nur über die zukende Schulter hinweg sah er mit aufgeworfenen Lippen nach Gregor zurück. Und während Gregors Rede stand er keinen Augenblick still, sondern verzog sich, ohne Gregor aus den Augen zu lassen, gegen die Tür, aber ganz allmählich, als bestehe ein geheimes Verbot, das Zimmer zu verlassen. Schon war er im Vorzimmer, und nach der plötzlichen Bewegung, mit der er zum letztenmal den Fuß aus dem Wohnzimmer zog, hätte man glabuen können, er habe sich soeben die Sohle verbrannt. Im Vorzimmer aber streckte er die rechte Hand weit von sich zur Treppe hin, als warte dort auf ihn eine geradezu überirdische Erlösung (109$10)$. 
The Prokurist had turned away at Gregor's first words, and, with protruding lips, only stared back at him over his twitching shoulder. He did not keep still for a moment while Gregor was speaking, but moved towards the door without taking his eyes off him. He moved very gradually, as if there were a secret prohibition on leaving the room. He was already at the hall, and the sudden movement with which he took his last step out of the room would have made one believe that he had just burned the soles of his feet. In the hall, he stretched his right hand far out towards the stairway as if an almost supernatural redemption were waiting for him there (101-02; modified).

Shaken with fear, the Prokurist forgets his mandate, relinquishes the aliena negotia, and flees the apartment in a panic, no longer attending to the concerns of the firm but rather taking care of himself alone. The hypothetical power that had hitherto supported the commissary - the force that, to use Cicero's phrase, legitimized him to act "as if he were almost a certain sort of master" (quasi quidam paene dominus) quickly dissolves as soon as the Prokurist discounts his representative and executive functions, and instead seeks to protect himself for his own sake. Hypotheses, however, are not lacking. Other "quasi" powers intrude upon the scene, as the flight is described by a series of unreal instances and contrafactual statements, grammatically marked by the subjunctive mood. The Prokurist's movements are at first inhibited "as if there were a secret prohibition" (als bestehe ein geheimes Verbot); then, with a sudden movement, he escapes so fast that one would think, "he had just burned the soles of his feet" (er habe sich soeben die Sohle verbrannt); until finally, he reaches out toward the staircase, "as if an almost supernatural redemption were waiting for him there" (als warte dort auf ihn eine geradezu überirdische Erlösung). The agent's functionalized being, motivated throughout by a presumptive potency, is suddenly threatened by other presumptions, until, in one final gesture, he stretches out his right hand as far as he can, groping for the "supernatural" authority of the firm that would deliver him. As a proxy sent to take care of a matter for the company, the Prokurist depended on an external, absent power; and it is precisely this power that abandons him as soon as he fears for his own life. He falls into a frightening independence that leaves him scrambling to reestablish the redemptive link of his principal, reaching out for the 
authority that would again empower him against what he perceives to be an existential threat.

The procurator, in other words, has two bodies: a hypothetical, more or less unassailable body that is nothing but an instrument of higher authority; and a real, vulnerable body, unmoored from this kind of empowerment. Whereas the protective, even redemptive system of representation is upheld by dependence, the relinquishment of the proxy function introduces a reminder of human independence. ${ }^{16}$ Although Kafka's Prokurist experiences this independence as a terrifying loss of power, others may understandably see this loss as liberating: no longer a non-subject, no longer a mere organ of authority, no longer a filius or a servus acting on the concerns of another entity, the one who has thus gained independence is now free to serve his own interests. That is not to say that this freedom is not frightening: Gregor Samsa himself discovers that he is free from work, free from the company, free from familial duties; but he purchases this freedom with a hideous metamorphosis that ultimately takes his life.

As many scholars have noted, the word Ungeziefer, usually translated as "vermin" or "bug," in addition to being a pejorative term against Prague Jews, stems from Middle High German usage to denote an "unclean animal unsuitable for sacrifice." 17 The Ungeziefer cannot be incorporated into any representational scheme. Unexpectedly transformed, Gregor Samsa falls outside every such system; unlike the Prokurist, he is neither a representative nor representable. Tellingly, when Kafka's publisher, Kurt Wolff, presented the author with suggestions for the book jacket cover illustrating the monstrous vermin, Kafka emphatically rejected any visual representation of the metamorphosed Gregor ("Das Insekt selbst kann nicht gezeichnet werden"); and instead first recommended that the artist depict the Prokurist. ${ }^{18}$ In Kafka's story, we immediately discover this Ungeziefer as someone who is no longer dependent on or attached to quasi-immortal entities, as a figure that can no longer be sacrificed for the sake of someone or something else. In classical Latin, procuratio can mean not only a "caring for" but also an "expiatory sacrifice" - "averting ... an evil omen or crime by offering the proper sacrifices."19 
Gregor is unrepresentable, but he is slow to realize this deficit. He makes an attempt to win the Prokurist over, with the hope that this agent may subsequently return to the company's headquarters and speak on Gregor's behalf. Through the closed door of his room, Gregor makes his appeal, asserting his desire to get back to work: "Be good enough to tell that to the boss and make my excuses to him!" (104/98) Once he emerges from his room, he again begs the Prokurist to relate his case-“Will you give a true account of all this?” (108/101) Yet, the sounds emitted from the insect are utterly incomprehensible. What might be a reasonable expectation under ordinary circumstances fails in the altogether exceptional case of an Ungeziefer, who is utterly incapable of being represented. No one, it appears, is able to take care of this ghastly creature. Even when Kafka shifts the problem of caring-for from a legal to a familial frame, failure painfully persists. After the Prokurist flees the apartment, Gregor's sister Grete tries to take care of him, serving as an intermediary between him and his baffled parents; but in the end, she too abandons the creature, assuming the cares and concerns of her mother and father, who ultimately decide that Gregor should be left to die. Why is Grete unable to continue caring for her suffering brother? Is it because Gregor, in his altered state, has lost the capacity to communicate? Like the Prokurist, his family never shows the slightest indication that they have understood any of his attempts to speak to them in a conciliatory tone. Gregor fails to convey his willingness to spare them by hiding beneath the sofa or by veiling his disgusting body with a bed-sheet. Is it because he cannot speak for himself that he loses the opportunity to have others speak for him? Has the presence of the Prokurist revealed that all speaking-for and all caring-for is ultimately an act of domination, reinforcing the interests of the powerful?

The link between power and care becomes explicit in treatments of the procurator in Roman poetry, which presents the agent as someone who willfully takes care of more than he was assigned, taking advantage of the trust that should define his office. For example, we find the following passage from Ovid's Ars amatoria, in which the poet offers instructions on how to seduce a married woman: 
Sint etiam tua vota, viro placuisse puellae: utilior vobis facuts amicus erit.

huic, si sorte bibes, sortem concede priorem: huic detur capiti missa corona tuo.

sive erit inferior, seu par, prior omnia sumat: nec dubites illi verba secunda loqui.

Tuta frequensque via est, per amici fallere nomen: tuta frequensque licet sit via, crimen habet. inde procurator nimium quoque multa procurat, et sibi mandatis plura videnda putat. ${ }^{20}$

Let it moreover be your wish to please the girl's husband: it will be more useful for the two of you to make friends.

If you drink by lots, give this one the better lot: this one should be given the garland taken from your head.

Whether he is below you or equal, let him take all things first: do not hesitate to second whatever he says.

It is a safe and well-trodden path to deceive by the name of friend: however safe and well-trodden the path may be, it is still a crime.

Thence the procurator also procures far too much, and counts on seeing more than he was charged with.

Well after he abandoned a promising legal-oratorical career, Ovid employs his poetic talents to provide morally questionable advice to young men eager to improve their success in trials of love. With his typically keen sense for the nature of public offices, Ovid's directives provocatively align the seducer's position with that of the procurator. Allusion is made to the diplomatic finesse that would characterize a steward so entrusted, a quality that should appear pleasing to the dominus, showing full agreement with the views of his master who, thus assured of his priority status, would willingly authorize his deputy to perform various duties in his stead. The poet accordingly instructs the would-be seducer to ingratiate himself to the man of the house, to grant him every privilege and give him the garland, which in conventional love poetry ought to be bestowed to the beloved. In essence, the philanderer should pose as a trustworthy friend, presenting himself as pure in motive, which makes it all the easier to deceive. Ovid not only admits the established and sure-fire nature of this approach - "a safe and well-trodden path" - but also its blatant criminality, designed to render the husband silent and absent. The oftfrequented path, of course, is not only laid for the womanizer but also for the 
husband, who will presumably exit by the very same road that leads the intruder to his prey. And just like the procurator who takes care of too much, the seducer will manage everything, once the dominus quits his abode. For the outbound path is also an all-too-penetrable, all-too-pregnable inroad. If the intruder is a procurator, then the husband, although present for now, is already marked out as one soon to depart. Martial subsequently devotes one of his epigrams to the selfsame plot:

Crispulus iste quis est, uxori semper adhaeret qui, Mariane, tuae? crispulus iste quis est? nescio quid dominae teneram qui garrit in aurem et sellam cubito dexteriore premit? per cuius digitos currit levis anulus omnes, crura gerit nullo qui violata pilo? nil mihi respondes? "uxoris res agit" inquis "iste meae." Sane certus et asper homo est, procuratorem voltu qui praeferat ipso: acrior hoc Chius non erit Aufidius. o quam dignus eras alapis, Mariane, Latini: te successurum credo ego Panniculo. Res uxoris agit? res ullas crispulus iste? res non uxoris, res agit iste tuas. ${ }^{21}$

This Curly, who is he? The one who's always hanging by your wife, who is he, Marianus? Who is this Curly, who whispers I know not what into the mistress's soft ear and leans on her chair with his right elbow? On all his fingers there runs a smooth ring, and he bears his legs violated by not a single hair? You have nothing to answer me? "He attends the affairs," you say, "of my wife." Well, he's a faithful and tough man, by his very face he shows himself to be a procurator: the Chian Aufidius will not be sharper. Oh, Marianus, how you deserve a slap from Latinus: I believe you will succeed Panniculus. He attends your wife's affairs? Does this Curly do anything? Yes, he attends not your wife's affairs, but yours.

The curly hair should give the lie to this smooth-talking Lothario, but poor Marianus is more of a buffoon than the stock clown Panniculus. In delegating his husbandly duties to another, the unsuspecting fool allows his crafty agent to 
perform every virile prerogative. Like Ovid's amorous disciple, this crispy opportunist oversees well beyond his mandate. The problem is not new, but rather has always haunted the institution of proxy agency. When Cicero adopts the figure of the procurator to describe the ideal orator-statesman, it is noteworthy that he attempts to correct what he regarded as a common abuse of power:

Ut enim tutela, sic procuratio rei publicae ad eorum utilitatem, qui commissi sunt, non ad eorum, quibus commissa est, gerenda est. ${ }^{22}$

For like guardianship, so the procuratio of the republic must be conducted for the benefit of those entrusted to one's care, not of those to whom it is entrusted.

In Cicero's view, the procuratores found in Ovid and Martial are especially insidious, insofar as they pose as serving and protecting their charge, but in fact only serve themselves.

As in the Kafka episode, both Ovid's didactic poem and Martial's witty epigram place the procurator in the private context of a domestic scene. The two Latin poems, moreover, are complementary, insofar as they both feature an internal addressee but with differing intent. Whereas the Ars amatoria passage offers instructions to a seducer on how to feign appearances, Martial's lines encourage a husband to see through the slick posturing. Ovid's husband remains anonymous, deictically marked by the demonstrative huic and thereby targeted as someone to be removed, while Martial's married man is addressed by name as someone to be reprimanded and thus encouraged to stay his ground. This poor man is also perhaps to be pitied. The pity may derive from the fact that, although he retains a name Marianus - his subjective agency is severely undercut by the advances of the suspicious Crispulus. Nil mihi respondes? - Marianus is already rendered impotent, incapable of responding, because he has renounced all responsibility. He has auctioned off his auctoritas to a procurator who presently speaks and acts in his place.

Ovid's immoral advice to the adulterer and Martial's scornful warning to the victim of adultery both link the transgressive maneuvers to procuratorial duties and 
thereby again broach the fundamental problem that troubles every scene of representation: If the representative takes the place of someone, what role remains for the represented $?^{23}$ As already suggested, the issue has always plagued systems of representation, from the wholly private affairs depicted by Ovid and Martial to general structures of legislation and governing broached by Cicero, from matters of domestic order to the terms of the social contract. The representative's ability to proceed independently on behalf of his client or his political constituents is premised on the possibility of ignoring the initial mandate, disregarding instructions, and thus acting at cross-purposes with the authorizing power.

In this regard, the problem of representation - of one person speaking or acting for another - is ultimately bound up with the ambivalence of security, insofar as both institutions are directly tied to equally ambivalent notions of cura. Securitas names that peace of mind, that tranquility of the soul, which attends the person free from bothersome worries. From the perspective of the delegating power, the procurator assumes the burdensome concerns that would otherwise be inhibiting. Yet, as both Ovid and Martial reveal, the procurator himself may become a fresh source of concern, a troublesome cura that would undermine one's sense of security. In desiring to be carefree, the person who delegates his power to speak and act risks becoming altogether careless. From the perspective of the procurator himself - "der Prokurist selbst" - assuming the mandate to speak for another may provide the protective security of trans-individual, even "supernatural deliverance" (überirdische Erlösung), but only when the representative sacrifices the freedom to speak for himself. As a monstrous Ungeziefer, Gregor Samsa appears no longer suitable for any sacrifice; incapable of any procuratorial service, he is now free from the concerns of his employer and his family. Yet, even the non-representable can be worked into a scheme of representation. Thus, at the end of Kafka's story, after Gregor finally perishes, his family is altogether rejuvenated, delivered from the many concerns that oppressed them. That is to say, Gregor ends up being the greatest procurator of all, not only by speaking for his family or acting on their behalf, but also by dying for them: he becomes an expiation, a procuratio, that is all the more powerful, insofar as it entails the sacrifice not of what can be but rather of 
what cannot be sacrificed. This failure reveals the limits of care in a way that upholds the value of care. Procuration, like security, may offer the promise of being free from care, but only by transferring concerns from one body to another.

In the end, being carefree cannot rid itself of the threat of becoming careless. Representation, the operative premise of liberalism, is incapable of securing the population from the kind of sovereign power generally ascribed to absolutism. All the same, representation remains the only viable means for tempering such power. The episodes of procuration discussed above underscore the ambivalence that continues to haunt our institutions. On the one hand, the procurator's office enables sovereign power to increase its reach of influence, while on the other hand, through this very same office, sovereignty becomes vulnerable to the failures or perversions of its representative body, all of which should at least serve as a poignant reminder, namely that one can never be without care without care.

NOTES

${ }^{1}$ For a nearly exhaustive account of the full semantic range of cura, see Manfred Hauser, Der römische Begriff Cura (Winterthur: Keller, 1954).

2 I fully trace the ramifications of this fundamental ambivalence throughout the history of the term in Security: Politics, Humanity, and the Philology of Care (Princeton: Princeton University Press, 2013).

3 Judith N. Shklar, "The Liberalism of Fear," in Liberalism and the Moral Life, Nancy Rosenblum, ed. (Cambridge: Harvard University Press, 1989), 21-38; here 21.

${ }^{4}$ Franz Kafka, Die Verwandlung in Gesammelte Werke (GW), 12 vols., Hans-Gerd Koch, ed. (Frankfurt a. M.: 2002), 1: 100. English: The Metamorphosis in The Complete Stories, Nahum N. Glatzer, ed. (New York: Schocken, 1983), 94, where the Prokurist is rendered "chief clerk." All subsequent citations from Kafka's story are from these editions. For clarity, I have modified the translations.

${ }^{5}$ Franz Kafka, Der Proceß, GW 3: 50. For further commentary on the figure of the Prokurist in Kafka's works, see Doreen Densky, "Proxies in Kafka: Koncipist FK and 
Prokurist Josef K." in Kafka for the Twenty-First Century, Stanley Corngold and Ruth V. Gross, ed. (Rochester: Camden House, 2011), 120-135. On procuracy in The Metamorphosis, see Kerstin Stüssel, In Vertretung: Literarische Mitschriften von Bürokratie zwischen frühe Neuzeit und Gegenwart (Tübingen: Niemeyer, 2004), 11316.

${ }^{6}$ Digest 3.3.1, in Iustiniani Augusti Digesta, seu Pandectae, 4 vols., Sandro Schipani, ed. (Milan: Giuffrè, 2005). Subsequent citations from the Digest are from this edition. ${ }^{7}$ Cf. A.H.J. Greenidge, Legal Procedure of Cicero's Time (Oxford: Clarendon, 1901), 237-38.

${ }^{8}$ Cicero De oratore 3.131, in Kazimierz Kumaniecki, ed. (Leipzig: Teubner, 1969), 3.131.

$9^{9}$ For an analysis of Cicero's use of the figure of procurator with numerous examples, see Gary Remer, "The Classical Orator as Political Representative: Cicero and the Modern Concept of Representation," The Journal of Politics 72 (2010), 1063-82. 10 Otto Hirschfield, Die kaiserlichen Verwaltungsbeamten bis auf Diocletian (Berlin: Weidmann, 1905), 382ff.; see also: A. N. Sherwin-White, "Procurator Augusti," Papers of the British School at Rome 15 (1939), 11-26, here: 12.

11 The German term Fürsprache, which denotes a general sense of "advocacy" or "speaking-for," finds no direct equivalent in the Latin lexicon. In Roman culture, the advocatus is literally the person who has been called upon to provide legal assistance (advocatio). Questions regarding the meaning of a law would be addressed to a iuris consultus or a legal expert (iuris peritus). The person who speaks on behalf of a defendant in court is the causidicus. Although the preposition pro- is indeed employed in many cases, e.g., "pro viro [...] dicere" ("to speak for a man," Cicero, Pro Milone 1) or "pro capite fortunisque regis [dicere]" ("[to speak] on behalf of the head and fortunes of the king," Cicero, Pro rege Deiotaro, 1.1), the speaker is simply an orator, and not a *pro-orator. I am grateful here to Michèle Lowrie, who commented on an earlier version of this article. On the ramifications of the German Fürsprache, see Rüdiger Campe, “An Outline for a Critical History of Fürsprache: 
Synegoria and Advocacy," Deutsche Vierteljahrsschrift für Literaturwissenschaft und Geistesgeschichte 82 (2008), 355-81.

12 Émile Benveniste, "L'expression du serment dans la Grèce ancienne," Revue de l'histoire des religions 1 (1948): 81-82.

${ }^{13}$ Johann W. Goethe, "Die Geschichte vom Prokurator" (Unterhaltungen deutscher Ausgewanderten), in Werke, 14 vols., Erich Trunz, ed. (Munich: Deutscher Taschenbuch Verlag, 1998), 6:185.

${ }^{14}$ Cicero, Pro Caecina 57, in M. Tulli Ciceronis Orationes, C.F.W. Müller, ed. (Leipzig: Teubner, 1906).

15 On this point, see Stephan Schaede, Stellvertretung: Begriffsgeschichtliche Studien zur Soteriologie (Tübingen: Mohr Siebeck, 2004), 139-140.

${ }^{16}$ I am alluding, of course, to Ernst Kantorowicz, The King's Two Bodies: A Study in Medieval Political Theology [1957], (Princeton: Princeton University Press, 1997).

${ }^{17}$ Etymologisches Wörterbuch des Deutschen (Munich: Deutscher Taschenbuch Verlag, 1993), s.v. “Ungeziefer.”

18 Kafka, Letter to Kurt Wolff, October 25, 1915, in Briefe 1902-1924, ed. M. Brod (New York: Schocken, 1958), 134-35.

${ }^{19}$ OLD, s.v. "procuratio." See Cicero, De legibus, where the orator refers to "expiationes et procurationes" (2.14.34); and Seneca, Nat. quaest. ("expiationes procurationesque," 2.35.1).

20 Ovid, Ars amatoria 1.579-88, in P. Ovidi Nasonis Amores, Medicamina faciei feminae, Ars amatoria, Remedia amoris, E. J. Kenney, ed. (Oxford: Clarendon, 1965). ${ }^{21}$ Martial, Ep. 5.61, in M. Valerii Martialis Epigrammaton liber quintus, Alberto Canobbio, ed. (Naples: Loffredo, 2011).

${ }^{22}$ Cicero, De officiis 1.85, M. Winterbottom, ed. (Oxford: Clarendon, 1994).

${ }^{23}$ See Remer, "The Classical Orator," 1069. 